\title{
PENERAPAN MODEL PEMBELAJARAN DRILL AND PRACTICE DIKOMBINASIKAN DENGAN DISKUSI KELOMPOK DILENGKAPI DENGAN MEDIA LKS UNTUK MENINGKATKAN KEMAMPUAN KERJASAMA DAN PRESTASI BELAJAR SISWA PADA MATERI KELARUTAN DAN HASIL KALI KELARUTAN KELAS XI MIA 1SEMESTER GENAP DI SMA AL ISLAM 1 SURAKARTA TAHUN AJARAN 2016/2017
}

\author{
Shanty Nurlianti \\ Program Studi Pendidikan Kimia, FKIP, Universitas Sebelas Maret, Surakarta, Indonesia \\ *Keperluan Korespondensi, telp:082221912113, email:shantynurlianti@gmail.com
}

\begin{abstract}
ABSTRAK
Penelitian ini bertujuan untuk meningkatkan: prestasi belajardan kemampuan kerjasama siswa kelas XI MIA 1 pada materi kelarutan dan hasil kali kelarutan di SMA AI Islam1Surakartadengan menggunakan model pembelajaran Drill and Practice dikombinasikan dengan diskusi kelompok dilengkapi media LKS Penelitian ini merupakan Penelitian Tindakan Kelas (PTK) yang dilakukan dalam dua siklus. Setiap siklusnya terdapat empat tahapan, yaitu perencanaan, pelaksanaan, observasi, dan refleksi. Subjek penelitian adalah siswa kelas XI MIA 1 SMA Al Islam 1 Surakarta tahun pelajaran 2016/2017. Teknik pengumpulan data melalui observasi, wawancara, kajian dokumen, angket dan tes. Teknik analisis yang digunakan dalam penelitian ini adalah deskriptif kualitatif. Berdasarkan hasil penelitian dapat disimpulkan bahwa: (1) penerapan model pembelajaran Drill and Practice dikombinasikan dengan diskusi kelompok dilengkapi dengan media LKS dapat meningkatkan prestasi belajar siswa kelas XI MIA 1 pada materi kelarutan dan hasil kali kelarutan di SMA AI Islam 1 Surakarta tahun pelajaran 2016/2017. Pada siklus I, ketercapaian prestasi belajaraspek pengetahuan sebesar $52,77 \%$ dan pada siklus II meningkat menjadi $80,56 \%$. Ketercapaian aspek sikap pada siklus I sebesar $80,55 \%$ dan meningkat menjadi $88,89 \%$ pada siklus II. Ketercapaian aspek keterampilan mencapai $100 \%$ (2) penerapan model pembelajaran Drill and Practice dikombinasikan dengan diskusi kelompok dilengkapi dengan media LKS dapat meningkatkan kemampuan kerjasama belajar siswa kelas XI MIA 1 pada materi kelarutan dan hasil kali kelarutan di SMA Al Islam 1 Surakarta tahun pelajaran 2016/2017. Pada siklus I, ketercapaian prestasi belajaraspek pengetahuan sebesar $77,78 \%$ dan pada siklus II meningkat menjadi $88,89 \%$.
\end{abstract}

Kata kunci : Drill and Practice, diskusi kelompok, LKS, kerjasama siswa, prestasi belajar

\section{PENDAHULUAN}

Sains atau IPA merupakan konsep pembelajaran alam yang berhubungan erat dengan kehidupan manusia, oleh karena itu pem-belajaran sains di sekolah akan memberikan manfaat yang penting. Manfaat pembelajaran sains antara lain meningkatkan mutu pendidikan terutama menghasilkan sumber daya manusia yang kritis dan memiliki sikap ilmiah sehingga mampu menye-lesaikan masalah dalam kehidupan sehari-hari serta mampu mengem-bangkan teknologi [1] Pembelajaran berbasis keteramplilan sains merupakan pembelajaran yang mengintegrasikan keterampilan berproses sains dalam penyajian materi. Pembelajaran ini menekankan pen-carian pengetahuan dan mengolah informasi yang dilakukan oleh siswa dengan dengan berfikir menggunakan prosedur proses ilmiah. Sehingga, siswa dapat mengembangkan keterampilan proses sains dalam menemukan pengetahuan, 
memahami konsep fakta yang berkaitan dengan materi ajar. Pembelajaran sains yang diberikan di Sekolah Menengah Atas (SMA) antara lain pelajaran Biologi, Fisika dan Kimia.

Kimia merupakan salah satu mata pelajaran wajib pada SMA kelas XI IPA. Kimia adalah cabang ilmu pengetahuan alam (IPA) yang mempelajari kajian tentang struktur, komposisi, sifat, dan perubahan materi serta energi yang menyertai perubahan tersebut [2]. Pada dasarnya, pelajaran kimia adalah pelajaran yang sangat dekat dengan kehidupan sehari-hari. Namun, mata pelajaran kimia sering sekali dianggap sulit oleh siswa karena sebagian besar konsepnya bersifat abstrak. Menurut hasil penelitian Osborne dan Collins sebagian besar siswa memandang kimia sebagai suatu pelajaran yang abstrak, sulit, dan tidak berhubungan dengan aktivitas kehidupan sehari-hari. Mereka menganggap bahwa dalam kehidupan sehari-hari mereka tidak perlu memahami reaksi kimia. Hal ini yang membuat siswa menjadi kurang tertarik untuk mempelajari kimia sehingga kimia dirasa menjadi salah satu pelajaran sulit bagi siswa.

Kimia mencakup tiga tingkat konseptual mencakup aspek mikro yaitu yang tidak dapat terlihat (ion, molekul, atom), aspek makro yaitu yang kasat mata dan aspek simbolis yang menghubungkan antara aspek mikro dengan aspek makro tersebu t[3]. Konsepkonsep abstrak pada pelajaran kimia membutuhkan penalaran ilmiah siswa untuk menghubungkan konsep mikroskopis dengan konsep makroskopis melalui simbol, sehingga belajar kimia merupakan kegiatan mental yang membutuhkan penalaran tinggi. Selain itu, penyebab kesulitan belajar siswa adalah kurangnya keterlibatan siswa di dalam pembelajaran secara aktif sehingga siswa tidak dapat memahami materi dengan maksimal.

SMA Al Islam 1 Surakarta merupakan salah satu sekolah yang menerapkan Kurikulum 2013. Dalam penerapannya, Kriteria Ketuntasan Minimal (KKM) untuk mata pelajaran kimia di SMA Al Islam1 Surakarta sebesar 75. Berdasarkan hasil wawancara terhadap guru mata pelajaran kimia SMA Al Islam 1 Surakarta tentang mata pelajaran kimia, bahwa kebanyakan siswa mengalami kesulitan karena pemahaman konsep yang kurang pada pembelajaran kimia. Menurut guru mata pelajaran kimia kelas XI di SMA Al Islam1 Surakarta diketahui bahwa beberapa materi kimia kelas XI semeter genap, salah satunya materi pokok Kelarutan dan Hasil Kali Kelarutan.

Materi Kelarutan dan Hasil Kali Kelarutan merupakan materi yang membutuhkan pemahaman konsep dan aplikasi dalam perhitungan. Sehingga, jika siswa kurang menguasai konsep materi tersebut dan materi sebelumnya yang berhubungan dengan ini yaitu kesetimbangan kimia, maka siswa akan mengalami kesulitan untuk menyelesaikan soal-soal yang berkaitan dengan materi kelarutan dan hasil kali kelarutan. Selain itu, materi Kelarutan dan Hasil Kali Kelarutan juga identik dengan variasi perhitungan hal ini membuat siswa mengalami kebingungan dan kurang tertarik dengan materi tersebut. Sehingga menyebabkan rendahnya prestasi belajar siswa. Oleh karena itu, diperlukan model pembelajaran yang sesuai kompetensi dasar ini supaya tujuan pembelajaran dapat tercapai secara maksimal dan membuat siswa berpartisipasi aktif dalam pembelajaran. Model pem-belajaran yang diterapkan tidak hanya menarik tetapi juga membentuk konsep di dalam pikiran siswa dengan pengalaman pembelajaran yang ada sehingga siswa mudah dalam memahami materi belajar.

Model pembelajaran yang diterapkan haruslah memudahkan siswa dalam memahami konsep Kelarutan dan Hasil Kali Kelarutan serta meningkatkan kemampuan siswa dalam memecahkan soal-soal pada materi ini. Drill and Practice merupakan salah satu model pembelajaran yang tepat untuk diterapkan pada materi ini. Model pembelajaran Drill and Practice digunakan untuk melatih kecakapan mental, misalnya perhitunganpenggunaan rumus dan lain-lain.[4] 
Menurut McDonough Metode Drill and Practice tepat diterapkan dalam pembelajaran materi hitungan, bahasa asing dan pening-katan perbendaharaan katakata. Metode Drill and Practice memiliki 5 tahap yaitu mendapatkan tujuan-tujuan, mendemonstrasikan penge-tahuan atau skill, memberikan latihan-latihan yang dibimbing, menge-cek pemahaman dan memberi latihan lanjut. Model pembelajaran ini diharapkan sesuai untuk diterapkan pada materi kelarutan dan hasil kali kelarutan yang pada dasarnya selain pemahaman konsep juga sangat membutuhkan banyak latihan dalam penyelesaian beragam soal yang terkait dengan materi. Selain itu, dengan model Drill and Practice dalam pemahaman konsep materi ini akan meningkatkan keaktifan siswa dalam menggali informasi melalui pemecahan masalah dalam soal.

Model pembelajaran Drill and Practice yang diterapkan dikombinasikan dengan diskusi kelompok bertujuan untuk meningkatkan aspek sosial yaitu kerjasama antar siswa di dalam satu kelompok untuk mencapai tujuan bersama. Hal ini dilakukan karena menurut hasil observasi, sebagian siswa lebih senang dan aktif dengan pembelajaran secara berkelompok dibandingkan secara individu. Namun tidak semua siswa ikut aktif dalam kelompoknya. Pada saat guru memberikan tugas secara berkelompok hanya dikerjakan oleh satu atau dua orang saja sedangkan siswa lain pasif bahkan tidak ikut serta dalam mengerjakan tugasnya. Selain itu, dengan diskusi kelompok maka siswa juga dapat melakukan interaksi atau bahkan bertukar pikiran dengan anggota kelompoknya, sehingga siswa dapat memperoleh pemahaman yang lebih baik terhadap konsep materi dari anggota kelompoknya [5]. Sehingga model Drill and Practice yang dikombinasikan dengan diskusi kelompok diharapkan dapat meningkatkan keaktifan belajar siswa khususnya kerjasama antar siswa dalam kelompoknya untuk pemecahan masalah tugas yang diberikan.

Selain penerapan model pembelajaran yang tepat, pembelajaran juga akan lebih efektif dengan penggunaan media pembelajaran, karena akan memudahkan guru dalam penyampaian materi dan memudahkan siswa dalam memahami materi. Pada penelitian ini media pembelajaran yang digunakan dalam pembelajaran adalah LKS. Lembar Kerja Siswa adalah lembaran yang berisi tugas yang harus dikerjakan oleh peserta didik baik secara individu ataupun kelompok. LKS biasanya berisi petunjuk dan langkah untuk menyelesaikan tugas yang berisikan kompetensi dasar yang harus dicapainya [6]. Lembar Kerja Siswa dirancang sebagai salah satu sumber belajar untuk mempermudah guru dalam menyampaikan materi dan memberikan penugasan kepada siswa secara tertulis sesuai dengan kompetensi dasar yang ditentukan. Lembar Kerja Siswa ini berisi soal-soal mengenai materi Kelarutan dan Hasil Kali Kelarutan. Lembar Kerja Siswa tersebut membantu siswa dapat mengonstruksi konsep-konsep secara mandiri maupun kelompok dan aktif untuk berlatih menjawab permasalahan pada materi tersebut.

Berdasarkan uraian permasalahan diatas, peneliti melakukan penelitian yang bertujuan mening-katkan kualitas kerjasama dan prestasi sebagai hasil belajar siswa pada SMAAI Islam 1 Surakarta.

\section{METODE PENELITIAN}

Penelitian ini merupakan Penelitian Tindakan Kelas (PTK) yang dilaksanakan dalam dua siklus. Setiap siklusnya terdapat empat tahapan, yaitu perencanaan, pelaksanaan, observasi, dan refleksi. Subjek penelitian adalah siswa kelas XI MIA 1 SMA Al Islam 1 Surakarta tahun ajaran 2016/2017. Pemilihan subjek dalam penelitian ini didasarkan pada hasil observasi yang dilakukan pada saat prasiklus, dimana subjek yang dipilih tersebut teridentifikasi mempunyai permasalahan dalam pembelajaran yaitu kerjasama siswa dan prestasi belajar yang rendah.

Data yang dikumpulkan meliputi data dari hasil observasi dan wawancara kerjasama siswa dan hasil penilaian 
prestasi belajar pada materi KSP yang meliputi aspek pengetahuan, aspek sikap, dan keterampilan baik pada siklus I maupun siklus II.

Teknik analisis data pada penelitian ini menggunakan analisis deskriptif. Analisis data menggunakan tiga tahap yaitu reduksi data (pengelolaan data), penyajian data (mengorganisasikan data kedalam suatu bentuk tertentu sehingga datanya terlihat lebih utuh), dan triangulasi atau pemeriksaan keabsahan data dengan memanfaatkan sesuatu yang lain diluar data tersebut sebagai pembanding data.

\section{HASIL DAN PEMBAHASAN}

Penelitian tindakan kelas ini bertujuan untuk meningkatkan kerjasama siswa dan prestasi belajar siswa kelas XI MIA 1 SMA AI Islam 1 Surakarta pada materi kelarutan dan hasil kali kelarutan dengan menerapkan model pembelajaran Drill and Practice dikombinasikan dengan diskusi kelompok dilengkapi LKS. Kerjasama siswa meliputi komunikasi interpersonal, kemampuan interaktif, pemecahan masalah dan mencapai tujuan bersama. Prestasi belajar yang diukur meliputi aspek pengetahuan, sikap dan keterampilan.

Penelitian ini dilakukan dalam 2 siklus yaitu siklus I dan siklus I. Masingmasing siklus terdiri dari tahap perencanaan, tahap pelaksana-an tindakan, tahap obsevasi dan tahap refleksi .

\section{Siklus I}

\section{a. Perencanaan}

Pada tahap perencanaan siklus I dilakukan penyusunan silabus, RPP, LKS, instrumen penilaian kerjasama siswa, serta instrumen prestasi belajar. Berdasarkan silabus alokasi waktu pembelajaran $13 \mathrm{JP}$ yang dibagi menjadi dua siklus dengan menggunakan model pembelajaran yang telah direncanakan oleh guru dan peneliti. Pembagian alokasi jam pelajaran dalam RPP pada tiap siklus adalah 7 jam pelajaran pada siklus 1 (dibagi menjadi 4 kali pertemuan) untuk menyampaikan materi dan 2 jam pelajaran untuk tes serta alokasi kegiatan praktikum diluar jam pelajaran, kemudian 4 jam sisanya untuk siklus 2 . Satu jam pelajaran berlangsung selama 45 menit dengan menerapkan model pembelajaran Drill and Practice yang dikombinasikan dengan diskusi kelompok menggunakan media LKS.

\section{b. Pelaksanaan}

Tahap pelaksanaan siklus I terdiri atas 5 kali pertemuan, dengan 4 kali pertemuan untuk penyampaian materi dan 1 kali pertemuan untuk evaluasi siklus I. Pembelajaran dilaksanakan selama 4 kali pertemuan dan setiap pertemuan pembelajaran diterapkan model sesuai model pembelajaran Drill and Practice. Pertemuan pembelajaran dilakukan pada tanggal 24 April selama 2 jam pelajaran. Langkah pertama pada setiap pembelajaran adalah guru memberikan apersepsi materi dengan memberikan pertanyaan-pertanyaan untuk membangun rasa keingintahuan siswa terhadap materi. Guru juga menjelaskan tujuan pembelajaran serta motivasi, selanjutnya guru mendemonstrasikan pengetahuan yaitu dengan memberikan penjelasan pengetahuan mengenai materi pada bab ini, pada tahap ini siswa memperhatikan penjelasan guru dengan seksama. Kemudian guru memberikan latihan terbimbing yaitu dengan contoh soal yang dikerjakan secara bersama antara guru dengan siswa. Untuk meningkatkan kerjasama siswa pada saat guru memberikan umpan balik untuk mengetahui pemahaman dengan menggunakan soal yang terdapat pada Lembar Kerja Siswa (LKS) untuk dikerjakan dan didiskusikan bersama dalam kelompoknya. Setiap siswa di dalam kelompok antusias berdiskusi dengan temannya untuk menyelesaikan soal-soal yang diberikan. Kemudian pada akhir pembelajaran guru memberikan pos test kepada siswa yang dikerjakan secara individu. Setelah itu guru membimbing siswa menyimpul-kan pembelajaran. Pada pertemuan kelima, dilaksanakan evaluasi siklus I yang meliputi penilaian aspek pengetahuan dimana siswa harus menjawab soal 
ulangan dan waktu yang tersisa digunakan untuk mengisi angket penilaian diri.

\section{c. Pengamatan}

Hasil penilaian observasi dan analisis hasil wawancara pada siklus I dapat dilihat ketuntasan aspek kerjasama. Hasil penilaian kerjasama siswa dapat dibuat kategori seperti pada Gambar 1.

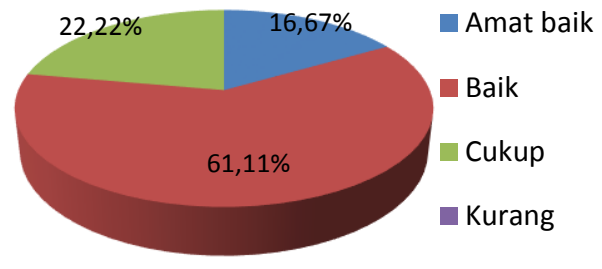

Gambar.1 Diagram Pie Ketuntasan Aspek Kerjasama Siklus I

Berdasarkan diagram pie diatas ketuntasan aspek kerjasama siswa mencapai $77,78 \%$ siswa yang. Hal ini berarti ketuntasan kerjasama siswa berdasarkan observasi telah mencapai target yaitu $70 \%$. Namun masih terdapat sekitar $22,22 \%$ siswa yang belum dapat bekerjasama dengan baik, seperti masih belum percaya diri mengeluarkan ide, belum dapat mengambil keputusan saat berdiskusi dan masih bekerja secara individu.

Hasil penilaian aspek pengetahuan bisa dilihat pada Gambar.2

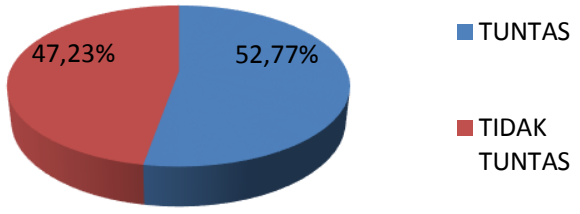

Gambar.2 Diagram Pie Ketuntasan Aspek Pengetahuan Siklus I

Gambar 2 menunjukkanbahwa siswa yang nilai yang tuntas masih di bawah target siklus I yaitu $70 \%$.

Pada siklus I terdapat 5 indikator yang tercapai dari total 7 indikator, yaitu materi yang lebih cenderung pada penerapan teori dan perhitungan. Berikut tabel ketuntasan masing-masing indikator dapat diilihat pada tabel 1.
Tabel 1 Ketuntasan Indikator Aspek Pengetahuan.

\begin{tabular}{|c|c|c|c|c|}
\hline \multirow{2}{*}{$\begin{array}{c}\text { Indikator } \\
\text { Kompetensi }\end{array}$} & \multirow[t]{2}{*}{ No } & \multicolumn{2}{|c|}{$\begin{array}{c}\text { Ketuntasan } \\
(\%)\end{array}$} & \multirow[t]{2}{*}{ Ket } \\
\hline & & Soal & Ind & \\
\hline $\begin{array}{l}\text { Pengertian } \\
\text { larutan }\end{array}$ & 1 & 94,4 & 94,44 & Tuntas \\
\hline Kesetimbangan & 2 & 91,6 & 84,73 & Tuntas \\
\hline larutan jenuh & 3 & 77,7 & & \\
\hline Hubungan & 4 & 94,4 & 81,24 & Tuntas \\
\hline Ksp dengan & 5 & 77,7 & & \\
\hline tingkat & 6 & 91,6 & & \\
\hline kelarutan & 7 & 61,1 & & \\
\hline \multirow{3}{*}{$\begin{array}{l}\text { Pengaruh ion } \\
\text { senama }\end{array}$} & 8 & 44,4 & 65,74 & Belum \\
\hline & $\begin{array}{l}y \\
10\end{array}$ & $\begin{array}{l}15 \\
77,7\end{array}$ & & \\
\hline & 11 & 36,1 & 51,85 & Belum \\
\hline \multirow[t]{2}{*}{ Pengaruh pH } & 12 & 63,8 & & \\
\hline & 13 & 55,5 & & \\
\hline Menghitung & 14 & 80,5 & 73,15 & Belum \\
\hline kelarutan & 15 & 63,1 & & \\
\hline \multirow{2}{*}{$\begin{array}{l}\text { garam sukar } \\
\text { larut }\end{array}$} & 16 & 75 & & \\
\hline & 17 & 41,6 & 41,67 & Belum \\
\hline Reaksi & 18 & 55,5 & & \\
\hline \multirow{2}{*}{ pengendapan } & 19 & 44,4 & & \\
\hline & 20 & 25 & & \\
\hline
\end{tabular}

Analisis ketidaktuntasan indikator yang belum tercapai ada 5 indikator, yaitu pada indikator 3 pada soal no 7 siswa bingung melanjutkan mencari massa zat ketika sudah diketahui kelarutannya. Pada indikator pengaruh ion senama siswa kurang teliti dalam menghitung jumlah spesi ion senamanya, sehingga hasil Ksp nya salah. Pada indikator menentukan $\mathrm{pH}$ larutan dari harga Kspnya dan sebaliknya, siswa juga tidak memperhatikan jumlah $\mathrm{OH}^{-}$yang mempengaruhi Ksp. Pada indikator garam sukar larut, siswa kesulitan dan masih bingung menghitung massa zat terlarut dan konsentrasi ion. Sedang-kan pada reaksi pengendapan siswa masih bingung menentukan ion penyusun dari Ksp yang diketahui.

Hasil angket dan observasi sikap dapat dilihat pada Gambar.3 berikut:

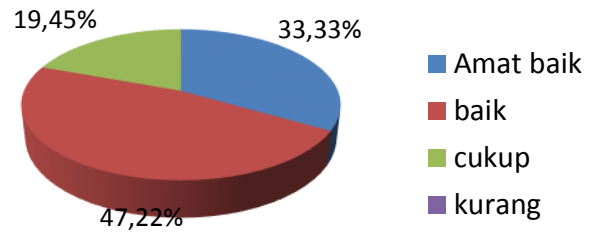

Gambar.3 Diagram Pie Ketuntasan Aspek sikap Siklus I 
Berdasarkan hasil ketuntasan akhir aspek sikap siswa maka sebesar ketuntasan aspek sikap belajar siswa adalah 80,55\%. Pada siklus 1 masih terdapat $19,45 \%$ siswa yang tidak tuntas, hal ini dikarenakan sampai pada akhir pertemuan pembelajaran masih terdapat siswa yang tidak memenuhi ketercapaian indikator seperti masih malu-malu dan hanya membaca saat mempresentasikan hasil diskusi. Selain itu masih terdapat siswa yang masih canggung untuk mengeluarkan pendapat saat pembelajaran.

Hasil observasi aspek keterampilan praktikum dan penilaian laporan praktikum dapat dilihat pada Gambar.4 berikut:

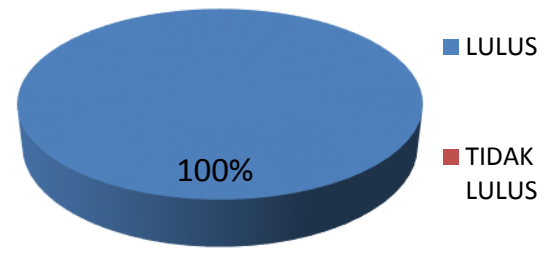

Berdasarkan Penilaian keterampilan siklus 1, diperoleh hasil bahwa persentase siswa yang tuntas adalah $100 \%$. Hasil ini telah mencapai target penelitian yait $70 \%$, sehingga peneliti memutuskan untuk tidak melakukan penilaian keterampilan pada siklus II.

\section{d. Refleksi}

Hasil penilaian siklus I yang dilakukan menunjukkan masih terdapat aspek yang belum mencapai target yaitu aspek pengetahuan. Sehinga perlu dilakukan perbaikan agar aspek pengetahuan mencapai target. Meskipun aspek kerjasama siswa dan sikap telah mencapai target, tetapi perlu ditingkatkan lagi. Oleh karena itu, perlu dilaksanakan siklus II yang diharapkan dapat mencapai target yang sudah ditentukan. Pada siklus II akan menerapkan model pembelajaran yang sama dengan jumlah anggota kelompok dan pembagian siswa yang tuntas pada siklus I dibagi secara merata disetiap kelompok. Perubahan ini diharapkan dapat membantu temannya yang belum paham menjadi paham sehingga ketuntasan siswa meningkat.

\section{Siklus II}

\section{a. Perencanaan}

Pada siklus II ini guru lebih memfokuskan pada siswa yang pada evaluasi siklus II mendapatkan nilai yang tergolong rendah dibandingkan temantemannya. Guru juga memberikan motivasi dan mengarahkan siswa untuk tidak segan dan lebih aktif dalam bertanya dan menyampaikan pendapatnya kepada guru dan temannya. Disamping itu, perbaikan juga dilakukan terkait dengan pembagian kelompok untuk diskusi. Kelompok diskusi pada siklus II ini dibagi berdasarkan nilai yang telah didapat siswa pada evaluasi siklus I dimana setiap kelompok terdiri dari 4-5 orang siswa. Hal ini dilakukan agar siswa yang sudah tuntas di siklus I dapat membantu temannya yang belum tuntas dalam satu kelompok tersebut dalam belajar sehingga dapat tuntas pada evaluasi siklus II.

\section{b. Pelaksanaan}

Siklus II ini dilaksanakan dalam 2 kali pertemuan, yaitu 1 kali pertemuan untuk penyampaian materi dan 1 kali pertemuan untuk evaluasi siklus II. Pada pertemuan pertama, guru menjelaskan kepada siswa bahwa pembelajaran ini lebih difokuskan pada 5 indikator kompetensi yang belum tuntas pada siklus I.

Pembelajaran siklus II ini juga menerapkan model pembelajaran Drill and Practice dikombinasikan dengan diskusi kelompok yang dilengkapi dengan media LKS. Pada awal pembelajaran guru memberikan apersepsi untuk mengingatkan materi sebelumnya, kemudian guru menjelaskan materi kepada siswa dan memberikan soal latihan kepada siswa untuk berdiskusi dalam kelompoknya menyelesaikan soal tugas kelompok yang diberikan. Siswa memperhatikan penjelasan guru dan mencermati materi pada LKS. Kemudian guru meminta siswa untuk mempresentasikan hasil diskusinya di depan kelas. Kegiatan pembelajaran dilanjutkan dengan post test secara individu dan kemudian di akhir pembelajaran guru beserta peserta 
didik menarik kesimpulan dari pembelajaran pada hari tersebut.

Pertemuan kedua pada siklus II yaitu pelaksanaan tes evaluasi dilaksanakan pada tanggal 15 Mei 2017 berlangsung selama 2 jam pelajaran atau 90 menit. Pembagian alokasi waktu tes yaitu 45 menit pertama siswa mengerjakan soal tes pengetahuan, kemudian 30 menit selanjutnya untuk sesi wawancara kerjasama dan pengisian angket sikap.

\section{c. Pengamatan}

Hasil observasi dan analisis tes yang sudah dilakukan pada siklus II dapat dilihat dari hasil pada aspek sikap:

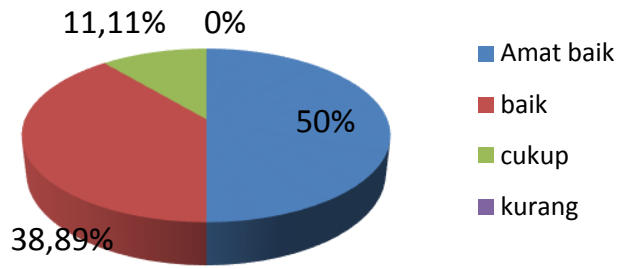

Gambar 5 Diagram Pie Ketuntasan Aspek sikap Siklus II

Berdasarkan gambar 5 dapat disimpulkan pada siklus II ini 88,89\% siswa sudah tuntas dalam aspek sikap. Hasil ini menunjukkan bahwa terjadi peningkatan ketuntasan dibandingkan dengan siklus I. Peningkatan in terjadi dikarenakan pada siklus II siswa lebih percaya diri dalam bertanya ataupun menjawab pertanyaan dari guru dan temannya. Selain itu siswa juga lebih bersungguh-sungguh dalam mengerjakan soal latihan baik kelompok maupun post test sehingga aspek tanggung jawab siswa juga meningkat.

Menurut hasil observasi dan wawancara siswa pada aspek kerjasama diperoleh hasil pada siklus II:

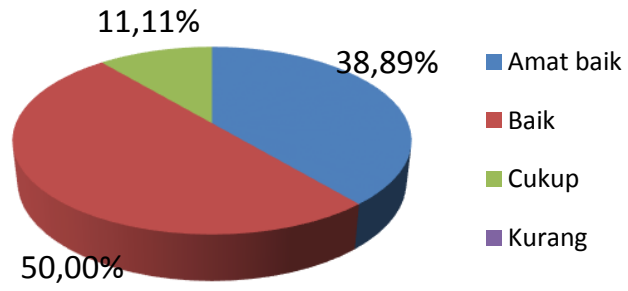

Gambar 6 Diagram Pie Ketuntasan Aspek Kerjasama Siklus II
Hasil yang disajikan pada Gambar 6 menunjukkan capaian siswa yang berkategori amat baik dan baik sudah melampaui target yang direncanakan dan semua indikator juga sudah mencapai target sebesar $75 \%$, sehingga, penilaian aspek rasa ingin tahu siswa dilakukan sampai siklus II ini.

Berdasarkan hasil tes pengetahuan siklus II pada indikator soal yang belum tuntas diperoleh hasil ketuntasan seperti pada diagram.

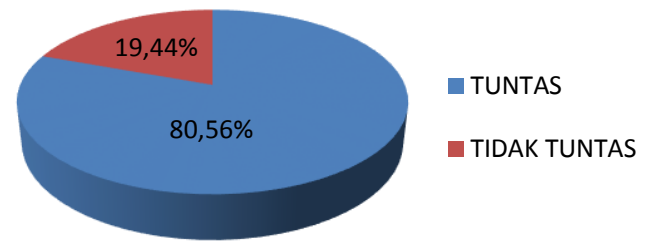

Gambar 7 Diagram Pie Ketuntasan Aspek Pengetahuan Siklus II

Berdasarkan hasil tes tertulis pada indikator soal yang belum tuntas yaitu sebanyak 10 soal pilihan ganda. Hasil analisis menunjukkan bahwa $80,56 \%$ atau sekitar 29 orang siswa telah tuntas pada aspek pengetahuan. Hal ini menunjukkan bahwa pada siklus II aspek pengetahuan telah melampaui target yaitu $70 \%$.

\section{d. Refleksi}

Berdasarkan data yang diperoleh pada siklus II, terlihat semua aspek meliputi aspek kerjasama siswa, pengetahuan, dan sikap mengalami peningkatan capaian dan sudah melampaui target sehingga penelitian di akhiri pada siklus II.

\section{Perbandingan Hasil Siklus I dan Siklus II}

Pada pembelajaran dengan model Drill and Practice dikombinasikan dengan diskusi kelompok terjadi peningkatan dari siklus I ke siklus II. Berdasarkan analisis aspek sikap ratarata ketercapaian keseluruhan aspek sikap siswa mengalami peningkatan dari siklus I ke siklus II. Hal ini disebabkan karena kegagalan pada siklus I membuat siswa semakin terdorong untuk lebih memanfaatkan sumber belajar, berani bertanya ataupun menjawab pertanyaan 
serta melakukan diskusi dan presentasi dengan sungguh-sungguh sehingga aspek sikap belajar siswa meningkat. Pada siklus I persentase ketuntasan aspek siswa adalah $80,55 \%$ sedangkan pada siklus II adalah 88,89\%. Perbandingan aspek sikap siklus I dan siklus II disajikan pada Gambar 8.

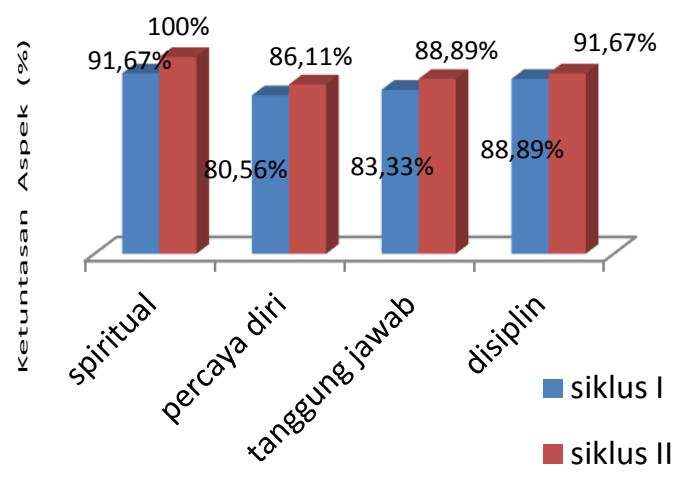

Gambar 8 Histogram Perbandingan siklus I dan II Aspek Sikap.

Perbandingan tiap aspek dalam aspek kerjasama siklus I dan siklus II disajikan dalam tabel 2.

Tabel 2 Perbandingan siklus I dan II Aspek Kerjasama.

\begin{tabular}{ccc}
\hline Siklus & Tuntas & Tidak Tuntas \\
\hline siklus I & $77,78 \%$ & $22,22 \%$ \\
siklus II & $88,89 \%$ & $11,11 \%$ \\
\hline
\end{tabular}

Pada siklus 1 ketuntasan siswa adalah $77,78 \%$ dari keseluruhan siswa ,dan $88,89 \%$ pada siklus II. Peningkatan ketuntasan pada siklus II disebabkan siswa yang tidak tuntas pada aspek pengetahuan di siklus I lebih bersungguh-sungguh berdiskusi dengan temannya supaya memahami cara menyelesaikan variasi soal yang diberikan. Selain itu siswa yang sudah bisa juga menjelaskan dengan baik kepada temannya dan bersama-sama mengerjakan tugas kelompoknya dengan baik. Setiap anggota kelompok bersungguh-sungguh mengerjakan tugas kelompok.

Pada aspek pengetahuan, ketuntasan pada siklus I dan siklus II mengalami peningkatan.. Pada siklus I terdapat 5 indikator kompetensi yang di dalamnya terdapat 10 indikator soal belum mencapai target ketuntasan, namun pada siklus II lima indikator tersebut telah mencapai ketuntasan. Perbandingan ketutasan aspek pengetahuan siklus I dan II disajikan dalam tabel berikut:

Tabel 3. Perbandingan siklus I dan II Aspek Pengetahuan

\begin{tabular}{ccc}
\hline Siklus & Tuntas & Tidak Tuntas \\
\hline siklus I & $52,77 \%$ & $47,23 \%$ \\
siklus II & $80,56 \%$ & $19,44 \%$ \\
\hline
\end{tabular}

Peningkatan persentase ketuntasan siswa pada aspek pengetahuan terjadi dikarenakan siswa yang tidak tuntas pada siklus I berusaha lebih giat pada siklus II. Pada siklus II siswa lebih memperhatikan dengan baik ketika guru memberikan materi dan contoh soal, siswa lebih aktif berdiskusi bertanya ketika merasa belum paham baik kepada guru dan kepada temannya ketika berdiskusi.

\section{KESIMPULAN}

Berdasarkan hasil penelitian yang telah dilakukan, maka dapat disimpulkan bahwa penerapan model pembelajaran Drill and Practice dikombinaasi dengan diskusi kelompok dengan media LKS SMA Al Islam 1 Surakarta tahun pelajaran 2016/2017 dapat meningkatkan kerjasama dan prestasi belajar siswa. Persentase ketercapaian kerjasama siswa pada siklus I sebesar $77,78 \%$ menjadi $88,89 \%$ pada siklus II. Peningkatan prestasi belajar siswa juga terlihat dari hasil prestasi belajar aspekpengetahuan sebesar 52,78\% menjadi $80,56 \%$. Aspek sikap sebesar $80,55 \%$ meningkat menjadi $88,89 \%$ dan ketercapaian aspek keterampilan sebesar $100 \%$.

\section{UCAPAN TERIMAKASIH}

Penelitian ini dapat terlaksana dengan baik karena bantuan dari berbagai pihak. Oleh karena itu penulis 
ingin mengucapkan terima kasih kepada KepalaSMA AI Islam 1 Surakarta, Bapak Drs. Abdul Halim atas izin yang diberikan kepada penulis untuk melakukan penelitian, dan kepada guru kimia kelas X Ibu Dra. Sri Hari Triana yang telah memberikan bimbingan selama penelitian, serta siswa-siswi kelas XI MIA 1 SMA AI Islam 1 Surakarta tahun pelajaran 2016/2017 yang telah membantu penulis dalam menye-lesaikan penelitian ini.

\section{DAFTAR RUJUKAN}

[1] Putra,S.R. (2013). Desain Belajar Mengajar Kreatif Berbasis Sains. Yogyakarta: Diva Press.

[2] Purba, Micahel. (2003). Kimia untuk Kelas $X$. Jakarta: Erlangga.

[3] Johnstone,A. H. (2006). Chemical education research in Glasgow in perspective. Chemistry Education and Practice, 7 (2): 49-63.
[4] McDonough, Sharon K. (2005). Way Beyond Drill and Practice: Foreign Languange Lab Activities in Support of Constructive Learning. Int'l $J$ of Instructional Media.Vol.28 (1).

[5] N.K. Roestiyah (2012). Strategi Belajar Mengajar. Jakarta: Rineka Cipta.

[6] Departemen Pendidikan Nasional. (2004). Pedoman Umum Pengembangan Bahan Ajar Sekolah Menengah Atas. Jakarta: Direktorat Pendidikan Menengah Umum Departemen Pendidikan Nasional. 